\title{
Multilevel UPQC Fed Grid Connected Hybrid System for Sag and Swell Mitigation
}

\author{
K.Manogna, P.Tejaswi
}

\begin{abstract}
This paper presents the cascade multilevel UPQC for sag and swell mitigation of a grid connected hybrid system. Power quality is the major problem facing by today's power system. Due to the use of power electronic converters and devices the harmonics are injected into the grid that may result in grid failure. To mitigate these harmonics custom power devices are used. UPQC is the custom power devise that is used in this paper. The seven level cascade multilevel converter is used for both the series and shunt inverters of UPQC for better harmonic distortion. This system is connected to the PV+WIND hybrid system to provide effective utilization of the resources. The UPQC contains a DC link which controls the Sag and Swell, LG Fault and improves the power quality of the system. This system is simulated in MATLAB/SIMULINK.
\end{abstract}

Index Terms-Cascade Multi Level Inverter (CMLI), Solar, Wind, PMSG, Voltage sag, Voltage swell, UPQC, DG, LG fault.

\section{INTRODUCTION}

Renewable integration involves many technically challenging issues which effects on the existing power and power quality. These involve voltage regulation, stability, power quality problems, etc. The customer mainly focuses on the quality of the power utilized. Losses and faults are also the reasons that causes the power quality problems. Electricity generation from the renewable sources has significantly increased due to limitless existence of sources such as solar and wind energy. The energy from the renewable sources varies continuously; there will be a lot of difficulty in interfacing renewable sources with the normal traditional electric grid. Due to the low efficiency of renewable sources, these generating systems are designed for small scale generation. Power electronic devices are widely used for the DG to connect it to the nominal grid which requires a special technology for the metering infrastructure. UPQC is the custom power device which mitigates the power quality issues like harmonics, sag, swell, power factor, voltage and current fluctuations.[1-3]

The multilevel converter fed UPQC filters the voltage and current harmonics. Both the series and shunt converters in the UPQC are replaced by the cascade H-bridge multilevel converters and it causes the absence of DC link.

The batteries provided in the cascade H-bridge MLI helps to provide the use of the DC link. Series filter is used to compensate the voltage whereas shunt filter compensates the current using multilevel strategy. This multilevel waveform

Revised Version Manuscript Received on 10 September, 2019.

K.Manogna, PG student (M-Tech), G.Narayanamma Institute of Technology and Science Hyderabad, Telangana, India

(Email: Manogna.k.mammu@gmail.com)

P.Tejaswi, Assistant Professor, EEE Department, G.Narayanamma Institute of Technology and Science Hyderabad, Telangana, India

(Email: tejaswetha.011@gmail.com) helps to mitigate the selected harmonics in the system. It is very important to maintain constant frequency and voltage when a system is connected to the grid to maintain better power quality and reliability of power system. Solar and wind energy generation systems are the two main renewable sources used in this paper as the hybrid generating system

In this paper Cascaded H-bridge MLI UPQC is used for the mitigation of sag, swell, LG fault and harmonics that occurs in the transmission line a part from the hybrid system interfacing into the grid. In voltage swell the nominal voltage increases from $10 \%$ to $90 \%$ of the RMS voltage whereas in voltage sag the phenomenon is exactly opposite to that of voltage swell. Power angle control is the technique that involves in the operation principle of the UPQC. The simulation results using MATLAB/SIMULINK are provided.

\section{MATHEMATICAL MODELLING}

\section{A. Solar Modelling}

The equivalent circuit of solar is provided as the two diode model which is shown in fig. 1 . The diode D1 is used to draw the current from the p-n junction of the solar panel where as the diode D2 acts as bypass diode and hence provide the path to the limiting current of the solar panel. the current generated from the sunlight is represented as photo current (IhU), the current passing through the diodes are represented as diode currents Id1 \& Id2. Series Resistance (Rse), Shunt Resistance (Rsh), Shunt Current (Ish), Series current (I=IhU) and Output Voltage $(\mathrm{V})$ are the ruling parameters of the two diode equivalent circuit of the solar cell.[3]

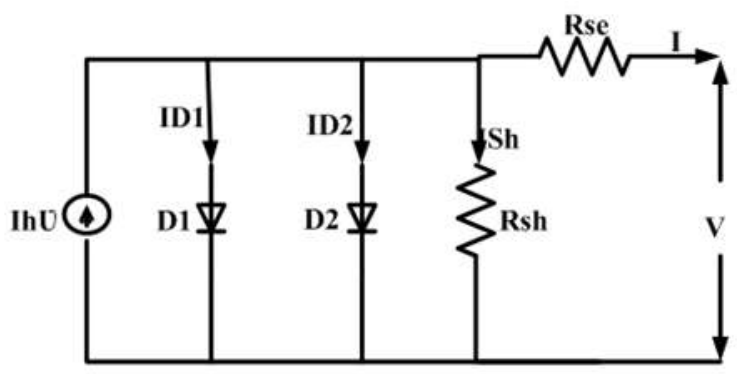

fig 1 Two diode model of solar PV system

(1) 


$$
\begin{aligned}
& I_{S h}=\frac{V+\left(R_{S e} \times I_{P V}\right)}{R_{s h}} \\
& I=I_{P V}-\left[\exp \frac{V+R_{S \varepsilon} \times I}{N \times V_{S}}\right)-1-I_{S 2}\left[\exp \left(\frac{V+R_{S \varepsilon} \times I}{N_{2} \times V_{S}}\right)-1\right] \frac{V+R_{S \varepsilon} \times I}{R_{h}} \\
& I_{D 1}=I_{S 1}\left[\exp \left(\frac{q \times V}{N_{1} \times K \times T}\right)-1\right] \\
& I_{D 2}=I_{S 2}\left[\exp \left(\frac{q \times V}{N 2 \times K \times T}\right)-1\right]
\end{aligned}
$$

The electrical parameters through which the solar module is working are provided below in the tabular column.

\begin{tabular}{|c|c|}
\hline \multicolumn{2}{|c|}{ Electrical Parameters } \\
\hline Maximum Power(PMax) & $245 \mathrm{~W}$ \\
\hline Voltage at PMax & $30.5 \mathrm{~V}$ \\
\hline Current at PMax & $8.04 \mathrm{~A}$ \\
\hline Short circuit Current & $8.73 \mathrm{~A}$ \\
\hline Open circuit Voltage & $37.5 \mathrm{~V}$ \\
\hline
\end{tabular}

Table 1 Solar PV parameters and ratings

The solar panel is build with these following ratings to get better output. The quantities used are maximum current, maximum voltage, maximum power, current at Pmax, voltage at Pmax and maximum power.

\section{B. WIND MODELLING}

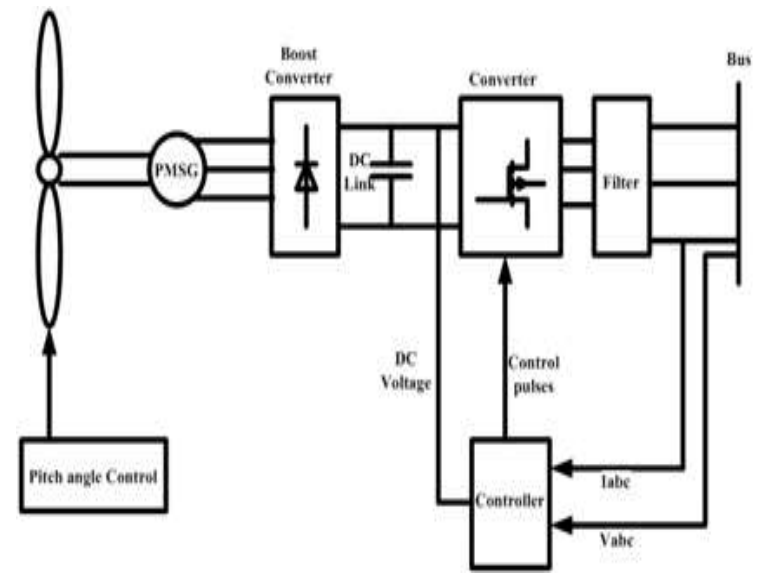

fig 2 Wind generation block diagram

Wind is the natural source of energy that is available in the kinetic energy which is of free of cost. The conversion of wind energy to electrical energy requires the use of turbines, generator, converters and control unit. The vertical axis wind turbine with permanent magnet synchronous generator (PMSG) is used in this paper. The parameters of the wind turbine are tabulated in the table 2.[4].

\begin{tabular}{|c|c|c|}
\hline Parameter & Symbol & $\begin{array}{c}\text { Value and } \\
\text { Units }\end{array}$ \\
\hline $\begin{array}{c}\text { Wind turbine rotor } \\
\text { radius }\end{array}$ & $\mathrm{R}$ & $1.25 \mathrm{~m}$ \\
\hline $\begin{array}{c}\text { Length of Blade } \\
\text { Swept area of Wind } \\
\text { turbine }\end{array}$ & $\mathrm{L}$ & $2.5 \mathrm{~m}$ \\
\hline Air density & $\mathrm{P}$ & $6.25 \mathrm{~m}-2$ \\
\hline & & $1.22 \mathrm{~kg} / \mathrm{m}-3$ \\
\hline Pitch angle & $\mathrm{V}$ & \\
\hline
\end{tabular}

Table 2 Mechanical parameters of wind turbine The power equation for wind turbine modeling is given by

$$
P_{m}=\frac{1}{2} C_{p(\lambda)} \rho A U_{W}^{3}
$$

The power coefficient $C_{p}$ is given by the formula

$$
C_{p}(\lambda, \beta)=C_{1}\left(\frac{C_{2}}{\lambda_{1}}-C_{2} \beta-C_{4}\right) \exp \frac{-C_{5}}{\lambda_{1}}+C_{6} \lambda
$$

The values of the coefficients $C_{1}=0.22, C_{2}=116, C_{3}=$ $0.4, C_{4}=5, C_{5}=12.6$ and $C_{6}=0.0068$

The relationship between the Power coefficient and the Tip speed ratio is given by the formula

$\omega_{m}=\frac{\lambda \mathrm{U}_{m}}{R}$

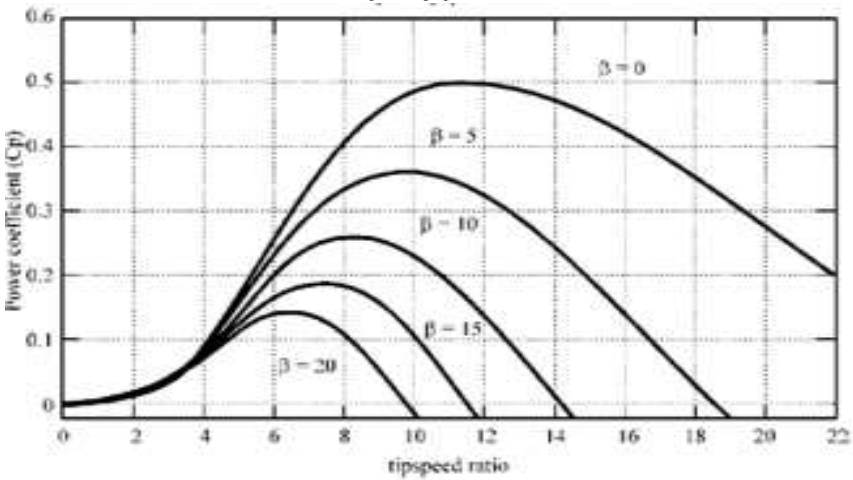

fig 3 characteristics of power coeffiecient vs tip speed ratio

Published By:

Blue Eyes Intelligence Engineering

\& Sciences Publication 
The modeling of PMSG requires the modeling of the $d-q$ axes which are peovided below.

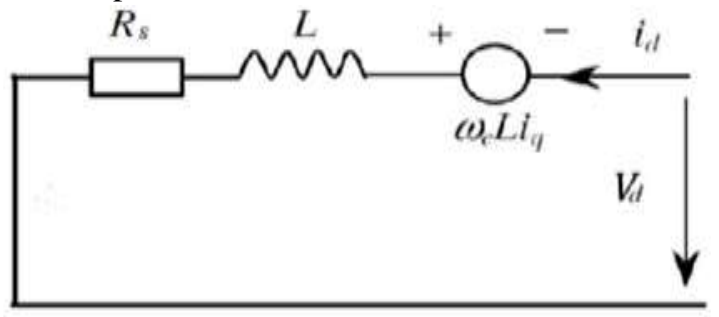

fig $4 \mathrm{~d}$ - axis model of Synchronous generator

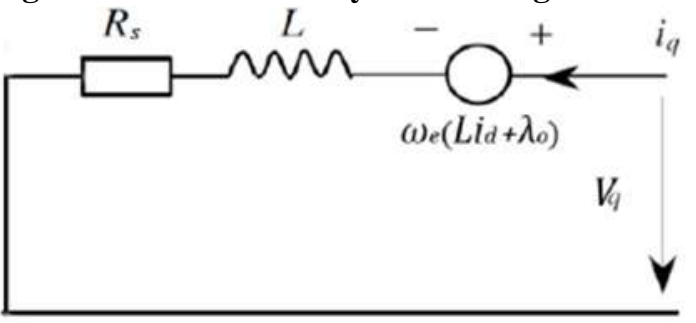

fig 5 q - axis model of Synchronous generator

The voltage equations for the $d-q$ axes are

$$
\begin{aligned}
& v_{d}=R_{s} i_{d}+L_{d} \frac{d i_{d}}{d t}-\omega_{e} L_{d} i_{q} \\
& v_{q}=R_{s} i_{d}+L_{d} \frac{d i_{d}}{d t}-\omega_{e} L_{d} i_{q}+\omega_{e} \phi_{m}
\end{aligned}
$$

The $\mathrm{Vd}$ and $\mathrm{Vq}$ are the voltages of the DQ axes and Rs represents the stator resistance. $\mathrm{Ld}$ and $\mathrm{Lq}$ are the inductance of D and Q axis respectively. i_d \& i_q are the stator currents in $\mathrm{d}$ and $\mathrm{q}$ field.

The electrical parameters of the PMSG are listed in the table 3 .

\begin{tabular}{|c|c|c|}
\hline Parameter & Symbol & $\begin{array}{c}\text { Value and } \\
\text { Units }\end{array}$ \\
\hline $\begin{array}{c}\text { Stator resistance } \\
\text { Inductance on D } \\
\text { axis }\end{array}$ & $\mathrm{Rs}$ & $12.875^{\prime} \Omega$ \\
\hline $\begin{array}{c}\text { Inductance on Q } \\
\text { axis }\end{array}$ & $\mathrm{Ld}$ & $0.0085 \mathrm{H}$ \\
\hline $\begin{array}{c}\text { Permanent } \\
\text { magnet flux }\end{array}$ & $\wedge \theta$ & $0.0085 \mathrm{H}$ \\
\hline $\begin{array}{c}\text { Pole pairs } \\
\text { Moment of inertia }\end{array}$ & $\mathrm{J}$ & $0.175 \mathrm{~Wb}$ \\
\hline
\end{tabular}

Table 3 Electrical parameters of PMSG

The electrical torque is provided by the formula

$$
T_{m}=\frac{3}{2} p\left\{\phi_{m} i_{q}+\left(L_{d}-L_{q}\right) i_{d} i_{q}\right\}
$$

Where Tm is mechanical torque from the turbine, and $\phi \mathrm{m}$ is the electromagnetic torque of the turbine.

$\mathrm{d}-\mathrm{q}$ modeling of PMSG is used for converting wind energy to the electrical energy which is connected to the solar PV system for Hybrid modeling.

C. Single line to ground Fault

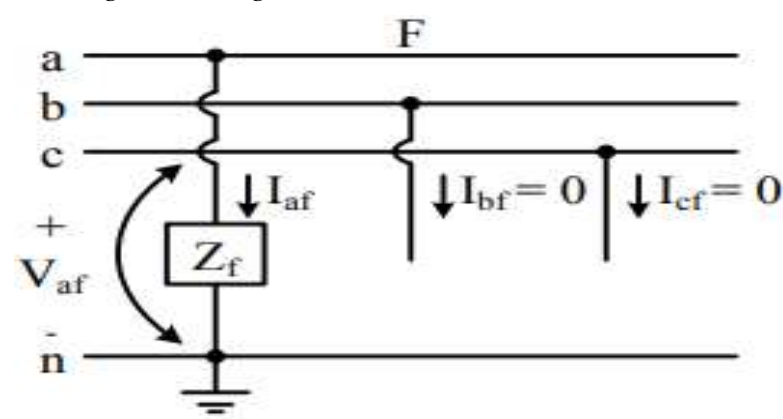

fig 6 single line to ground fault

In the fig 6 the LG fault is present at the phase A the fault currents and the fault voltages are given as

$$
\begin{aligned}
& I_{a o}=I_{a 1}=I_{a 2}=\frac{1.0 \angle 0^{\circ}}{Z_{o}+Z_{1}+Z_{2}+3 Z_{f}} \\
& I_{a f}=I_{a o}+I_{a 1}+I_{a 2} \\
& V_{a f}=Z_{a f} I_{a f}
\end{aligned}
$$

This LG fault causes increase in current in the phase A which causes the damage of the equipments in the power systems.

\section{Cascade H-bridge Multilevel converter}

Cascade Multi Level Inverter consists of H-bridges that are cascaded to provide multiple levels. In this paper we use 7 level CMLI to mitigate the harmonics. This multilevel inverter contains switches and batteries. The fig 7 represents the seven level CMLI.

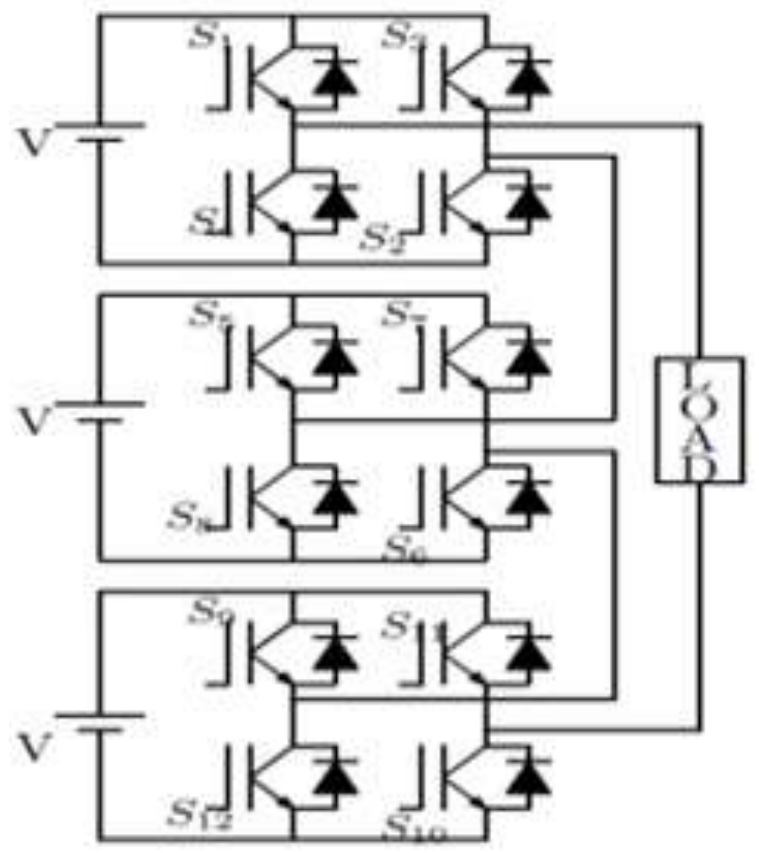

fig 7 Seven level CMLI

The switching sequence of the 7 level CMLI is given in the table 4

Published By: 


\begin{tabular}{|c|c|c|c|c|c|c|c|}
\hline$V_{0}$ & $+\mathrm{V}$ & $+2 \mathrm{~V}$ & $+3 \mathrm{~V}$ & 0 & $-\mathrm{V}$ & $-2 \mathrm{~V}$ & $-3 \mathrm{~V}$ \\
\hline$S_{1}$ & 1 & 1 & 1 & 1 & 0 & 0 & 0 \\
\hline$S_{2}$ & 1 & 1 & 1 & 0 & 0 & 0 & 0 \\
\hline$S_{3}$ & 0 & 0 & 0 & 0 & 1 & 1 & 1 \\
\hline$S_{4}$ & 0 & 0 & 0 & 1 & 1 & 1 & 1 \\
\hline$S_{5}$ & 0 & 1 & 1 & 0 & 0 & 0 & 0 \\
\hline$S_{6}$ & 1 & 1 & 1 & 1 & 1 & 0 & 0 \\
\hline$S_{7}$ & 0 & 0 & 0 & 0 & 0 & 1 & 1 \\
\hline$S_{8}$ & 1 & 0 & 0 & 1 & 1 & 1 & 1 \\
\hline$S_{9}$ & 0 & 0 & 1 & 0 & 0 & 0 & 0 \\
\hline$S_{10}$ & 1 & 1 & 1 & 1 & 1 & 1 & 0 \\
\hline$S_{11}$ & 0 & 0 & 0 & 0 & 0 & 0 & 1 \\
\hline$S_{12}$ & 1 & 1 & 0 & 1 & 1 & 0 & 1 \\
\hline
\end{tabular}

Table 4 switching sequence of seven level CMLI

This switching sequence is generated by the sinusoidal PWM technique. The triangular pulses are compared with the carrier sinusoidal waveform to generate these pulses which are provided as the switching patterns for the multilevel inverter.

\section{E. UPQC Modelling}

UPQC is the combination of both the series and shunt active filters that injects voltage and current into the transmission lines respectively.

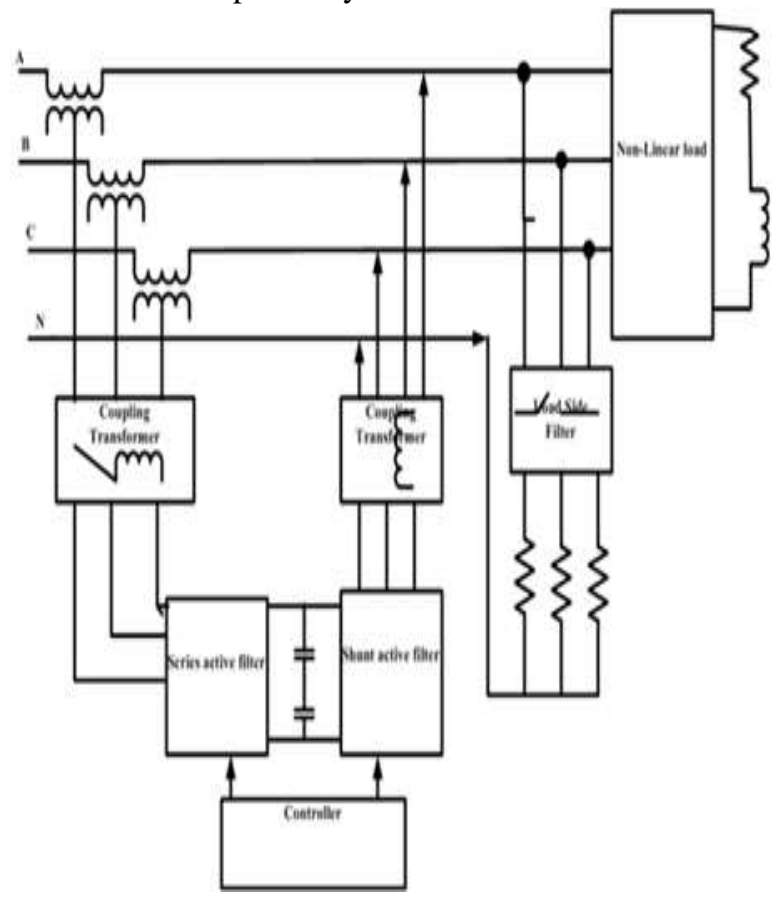

fig 8 UPQC circuit

\section{Shunt active filter:}

The currents injected into the transmission lines by using shunt active filters are given by

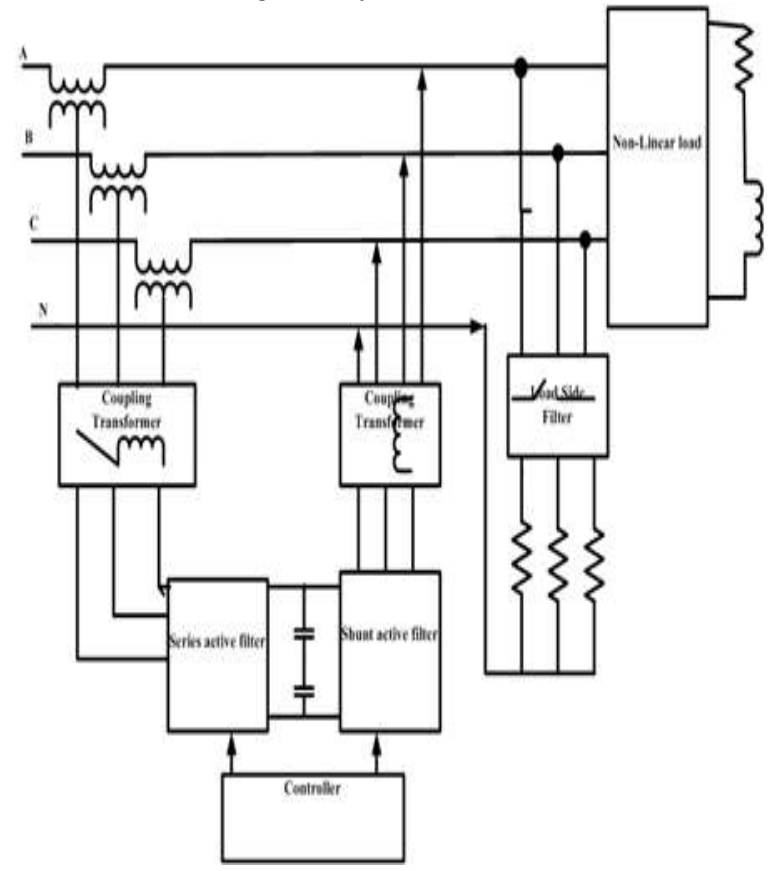

fig 3 UPQC circuit

$$
\begin{aligned}
& i_{f a} *=i_{s a} *-i_{a} \\
& i_{f b} *=i_{s b} *-i_{b} \\
& i_{f c} *=i_{s c} *-i_{c}
\end{aligned}
$$

The error signal is generated by comparing actual shunt currents with reference currents which are provided to the controller.

Series active filter:

Series controller injects the voltage and power angle into the transmission lines. The voltages injected are given by

$$
\begin{aligned}
& V_{f a} *=V_{s a} *-V_{a} \\
& V_{f b} *=V_{s b} *-V_{b} \\
& V_{f c} *=V_{s c} *-V_{c}
\end{aligned}
$$

The power angle injected into the transmission line are given by the formula

$$
\delta_{i n j}=\tan ^{-1}\left(\frac{R e\left[\mathrm{v}_{p q}\right]}{\operatorname{Im}\left[\mathrm{v}_{p q}\right]}\right)
$$

These error signals are provided to the PWM controller to generate pulses for the multilevel inverter. These pulses takes the sample of the sag, swell and LG faults and provides the signal to the PI controller of the SPWM generator. This controller generates the seven level waveform from the shunt and series inverters which are injected into the transmission lines to mitigate the faults 


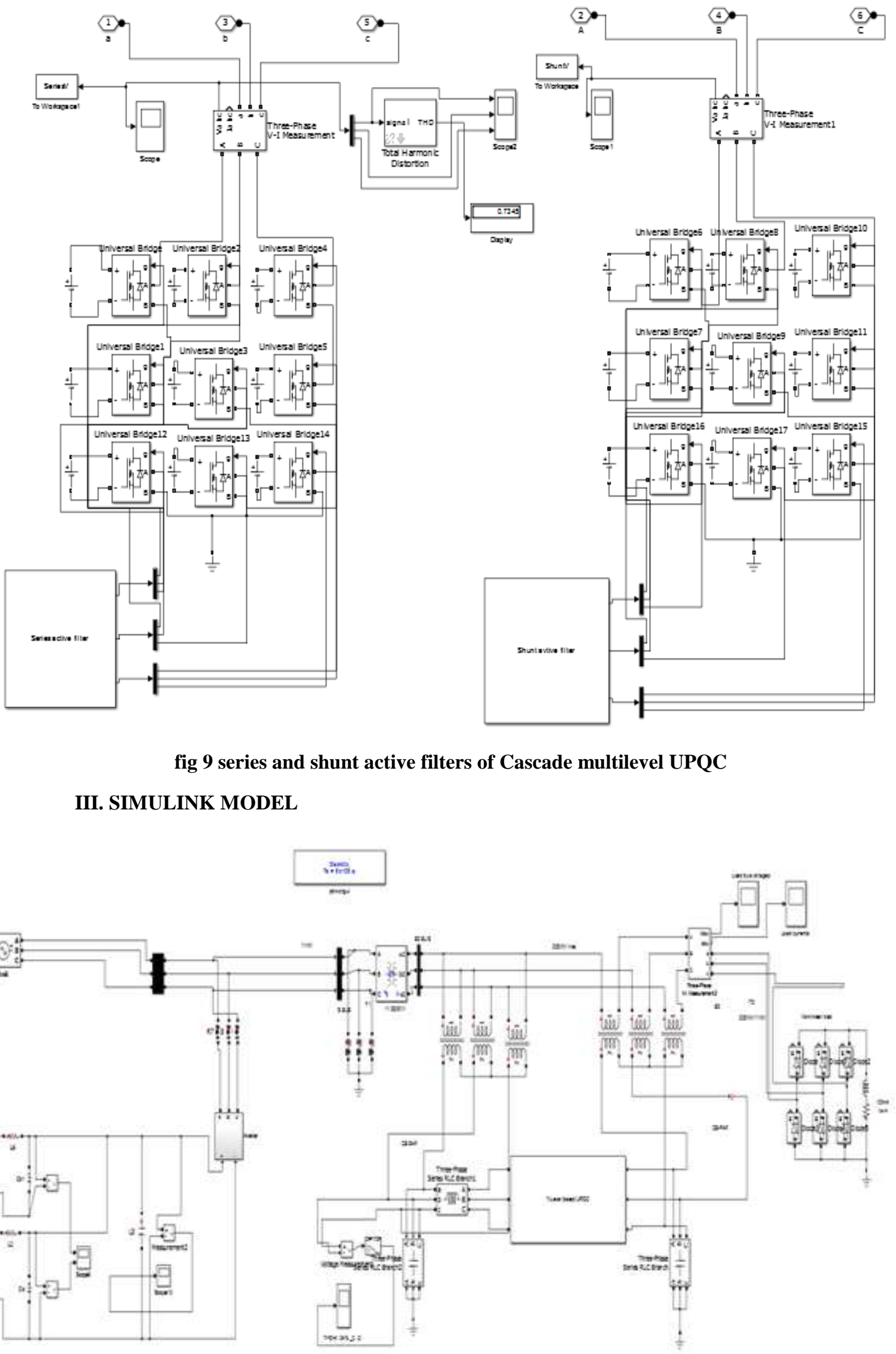

fig. 10 Simulink model of multilevel UPQC with Hybrid system 


\begin{tabular}{|c|c|}
\hline Input voltage & $380 \mathrm{~V}$ \\
\hline Input Current & $10 \mathrm{Amps}$ \\
\hline Sag & $190 \mathrm{~V}$ \\
\hline Swell & $470 \mathrm{~V}$ \\
\hline Fault Voltage & $420 \mathrm{~V}$ \\
\hline Fault Current & $35 \mathrm{Amps}$ \\
\hline
\end{tabular}

Table 5 simulation inputs to the grid

The Distribution system is designed with Grid of $380 \mathrm{~V}$ seconds with the peak voltage of $190 \mathrm{~V}$. The swell is injected from 0.05 seconds to 0.08 seconds with the peak voltage of $470 \mathrm{~V}$. LG fault is injected for about 0.2 seconds from 0.2 to $0.4 \mathrm{sec}$.

\section{RESULTS AND ANALYSIS}

The sag, swell and LG fault which is present in the input The distorted current waveform in the Input current is absent in the output current waveform. The power quality is improved in the output wave forms which is supplied to the load ends. The results for the simulation are given below with output waveforms.

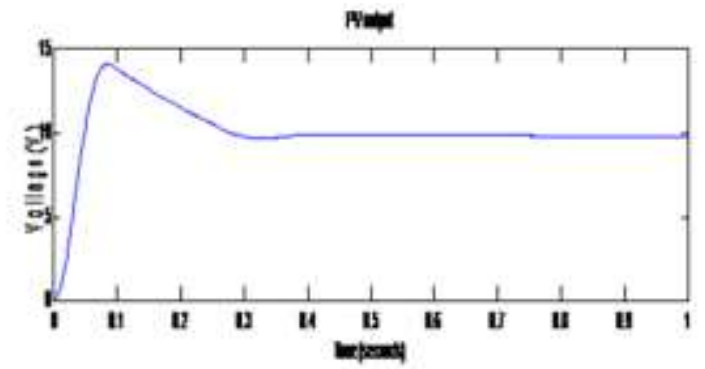

fig. 11 Solar PV output

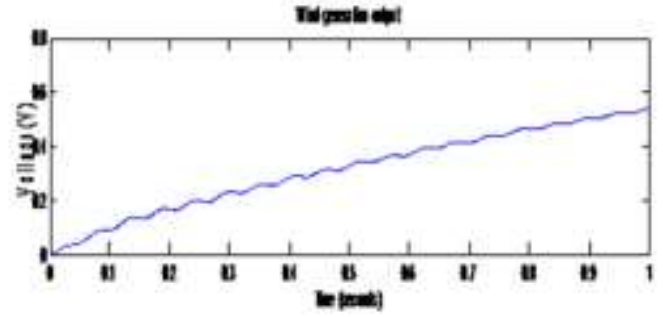

fig.12 Wind generation output $50 \mathrm{~Hz}$. The Sag is injected into the grid from 0.01 to 0.05 voltage waveform are mitigated in output Voltage waveform.

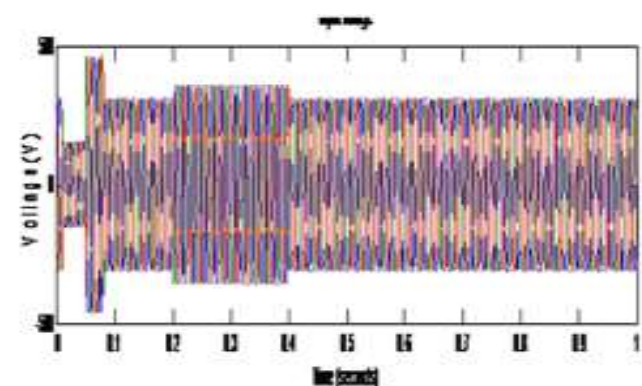

fig. 13 Input voltage with sag, swell and LG fault

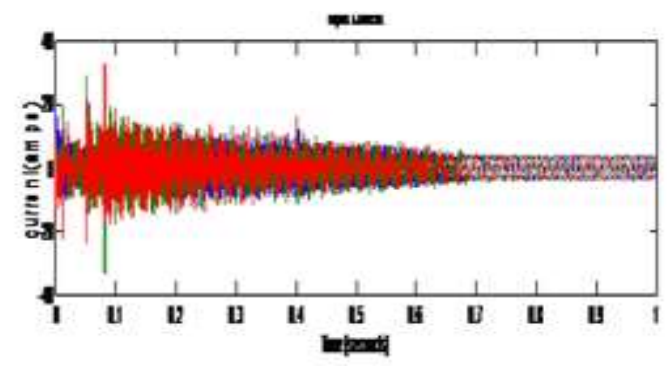

fig.14 Input Current during fault

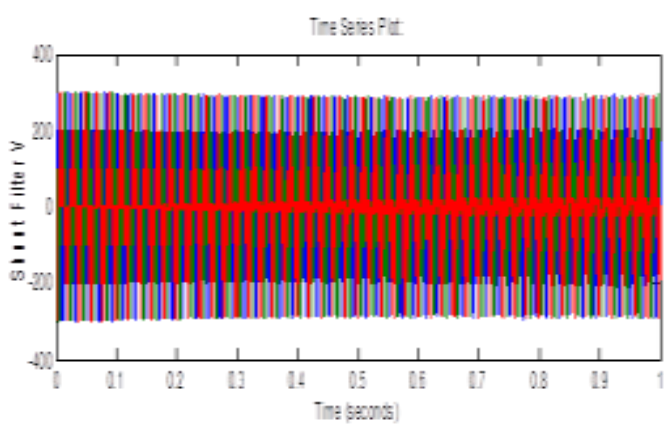

fig 15 Shunt filter Voltage

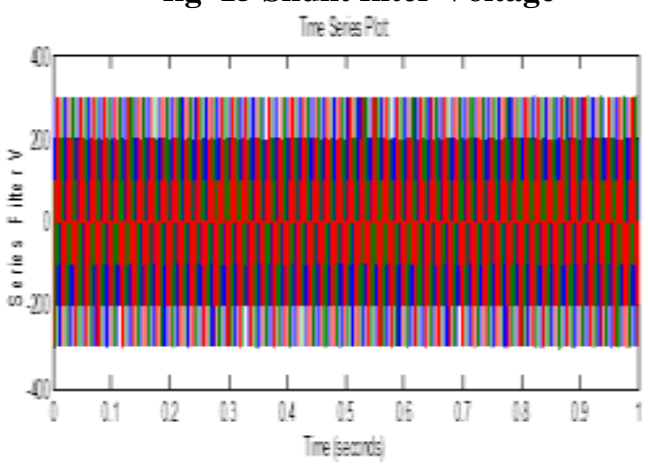

fig 16 series filter Voltage

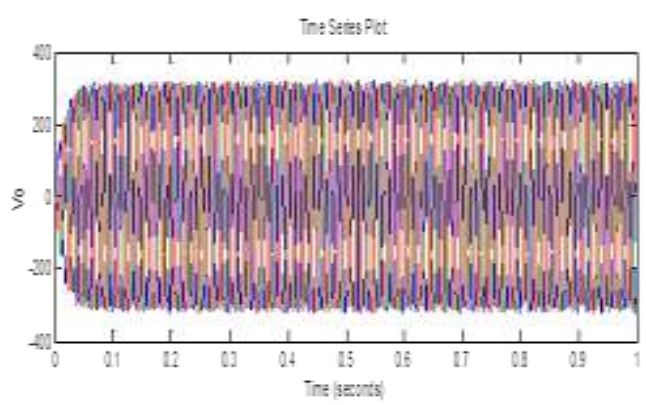

fig.17 Output Voltage at load ends

Published By: 


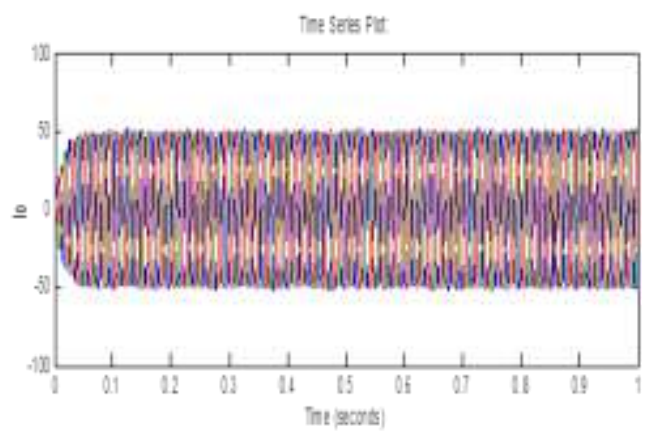

fig.18 Output Current at load ends

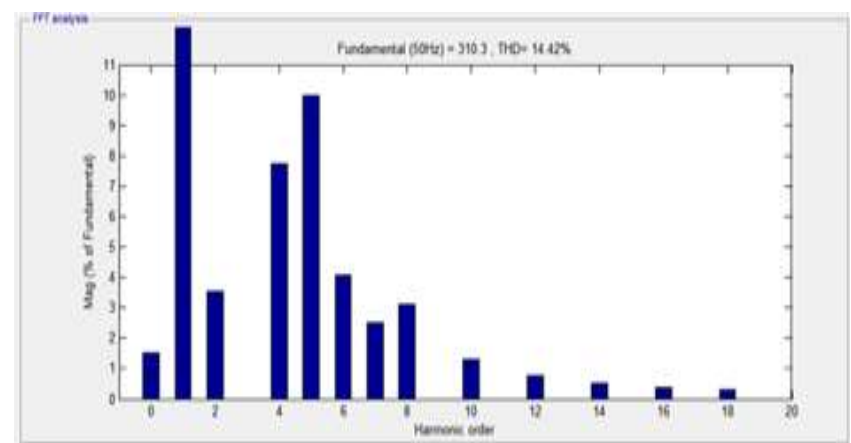

fig 19 Voltage harmonics at the input

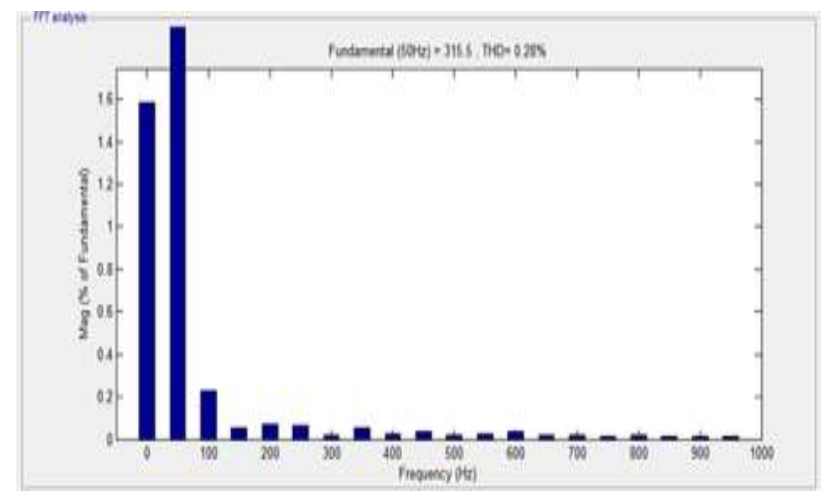

fig 20 Voltage harmonics at the output of load ends

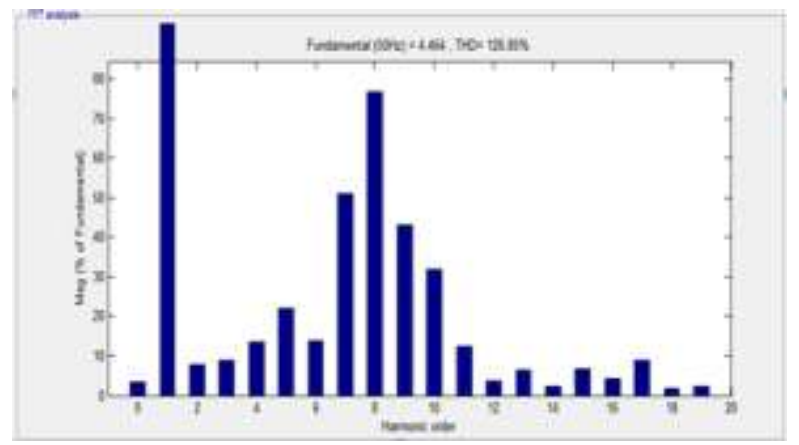

fig 21 current harmonics at the input

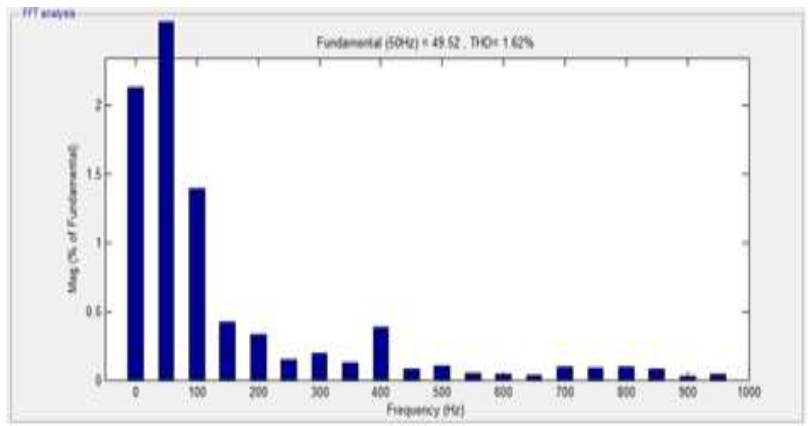

fig 22 current harmonics at the output of load ends

\section{CONCLUSION}

The disturbances and harmonics present in the voltages and currents are controlled by using the multilevel UPQC. The controller helped to provide the mitigation over the sag, swell, LG fault and harmonics. The hybrid system here helped us in providing the additional source a part from the traditional electrical source from the generators. The SPWM techniques provided the complete control over the fault current and sag and swell in the voltages and hence produced the better quality of power at load ends when compared to the conventional UPQC. But the UPQC fails to mitigate the voltage interruptions at the input side which can be controlled by providing a controlled DC source in it.

\section{REFERENCES}

1. M.T.L.Gayatri and Dr. Alivelu M. Parimi, "Mitigation of Supply \& Load Side Disturbances in an AC Microgrid Using UPQC,"IEEE Trans 2016 Biennial International Conference on Power and Energy Systems: Towards Sustainable Energy (PESTSE).

2. C.K.Sundarabalan and P.Sathishbabu, "Unified Power Quality Conditioner for Enhancement of Power Quality and Hybrid Power Generation Injection to Grid, "International Journal of Modern Engineering Research (IJMER) Vol.2, Issue.2, Mar-Apr 2012

3. Pavan Kumar, A.V., Parimi, A.M., Rao, K.U., "Implementation of MPPT control using fuzzy logic in solar-wind hybrid power system," 2015, IEEE International Conference on Signal Processing, Informatics, Communication and Energy Systems (SPICES), pp.1-5, 19-21, Feb. 2015.

4. B.O.Omijeh, C. S. Nmom, E. Nlewem., "Modeling of a Vertical Axis Wind Turbine with Permanent Magnet Synchronous Generator for Nigeria", IEEE International Journal of Engineering and Technology Volume 3 No. 2, February, 2013.

5. B. Rahmani, W. Li, and G. Liu, "An Advanced Universal Power Quality Conditioning System and MPPT method for grid integration of photovoltaic systems," Int. J. Electr. Power Energy Syst. , vol. 69, pp. 76-84, Jul. 2015.

6. Sarita Samal, Prakash Kumar Hota, "Power Quality Improvement by Solar Photo-voltaic/Wind Energy Integrated System Using Unified Power Quality Conditioners, "International Journal of Power Electronics and Drive System (IJPEDS) Vol. 8, No. 3, September 2017.

7. Jorge Santamaria, " Analysis of power systems under fault conditions", California state university, sacramento summer 2011.

8. Rathinam. A and Karthikeyan. $\mathrm{T}$ "Investigations on performance of multilevel inverter topologies for medium power applications", Shodhganga. http://hdl.handle.net/10603/196219.

9. Rajamani.V and Khannan.P "Modeling and simulation of UPQC in power systems to improve power quality", Shodhganga. http://hdl.handle.net/10603/42702. 